\title{
China's Foreign Assistance and Its Implications for the International Aid Architecture \\ Pan Yaling
}

\begin{abstract}
China is now emerging as one of the most important development partners in the world. Based on its double identities as both recipient and donor, China has developed some specialties in terms of international development assistance. What new elements has China brought to the international aid architecture? This essay argues that the Chinese foreign assistance theory has four unique features, namely prioritizing development without setting any precondition; building win-win relationships with recipient countries through promotion of their independent development and national interests; insisting on equality rather than moral preaching, as well as keeping strategic patience while avoiding technical short-sightedness. Despite such specialties, China's foreign assistance is still practiced under international frameworks; the changes it aims to make
\end{abstract}

Pan Yaling is Associate Professor at the Center for American Studies, Fudan University, China.

(C) 2015 World Century Publishing Corporation and Shanghai Institutes for International Studies China Quarterly of International Strategic Studies, Vol. 1, No. 2, 283-304 
should not be regarded as a "quiet revolution," but as an amendment to the existing international aid architecture.

Keywords: Foreign assistance theory; Chinese experience; sustainable selfdevelopment; international aid architecture.

\begin{abstract}
Along with its rapid rise, China has emerged as an important development partner, a fact that attracts intensive global attention to explore the theory, model, institution, policy, and practice of China's foreign assistance. ${ }^{1}$ Foreign researchers tend to focus on the institutions and strategic goals of China's foreign assistance, and the differences between China and traditional donors, while Chinese scholars, though devoting themselves to defending China's stance and refuting skepticism and criticism from the international community in general and the West in particular, usually fail
\end{abstract}

\footnotetext{
${ }^{1}$ For the summary of the most recent studies on China and other emerging donors, see Julie Walz and Vijaya Ramachandran, "Brave New World: A Literature Review of Emerging Donors and the Changing Nature of Foreign Assistance," Working Paper, No. 273 (Washington, D.C.: Center for Global Development, November 2011). There is a growing body of literature on this topic since 2011, for example, Liu Hongwu and Huang Meibo, Zhongguo Duiwai Yuanzhu yu Guoji Zeren de Zhanlue Yanjiu [Strategic Studies on China's Foreign Assistance and International Responsibility] (Beijing: China Social Science Press, 2013); Yasutami Shimomura and Hideo Ohashi, eds., A Study of China's Foreign Aid (London, UK: Palgrave Macmillan, 2013); Deborah Bräutigam, "Aid 'with Chinese Characteristics': Chinese Aid and Development Finance Meet the OECD-DAC Regime," Journal of International Development, Vol. 23, No. 5 (July 2011), pp. 752-764; Naohiro Kitano, "China's Foreign Aid at a Transitional Stage," Asian Economic Policy Review, Vol. 9, No. 2 (July 2014), pp. 301-317. It is important to note that while international academic and policy communities prefer to use the term "emerging donor," China prefers terms like "development cooperation partner" or "development donor" given the inequality nature of the term donor/recipient. For example, the White Paper of China's Foreign Aid claims that China's foreign assistance is conducted under the South-South cooperation framework. See Information Office of the State Council, the People's Republic of China, China's Foreign Aid (White Paper), April 2011, Beijing, http://www.scio.gov.cn/zxbd/nd/2011/Document/ $896900 / 896900 . h t m$. Such attitude is also adopted increasingly by the UN system, see, for example, UN, High-level Committee on South-South Cooperation, 17th Session, SSC/17/2, May 22, 2012, http://ssc.undp.org/content/dam/ssc/documents/HLC $\% 202012 / S S C \% 2017 \%$ $202 \% 20(C)$.pdf.
} 
to conceptualize and theorize Chinese aid practices in a comprehensive way. $^{2}$

Since the very beginning of the twenty-first century, an increasing number of Chinese scholars have been making efforts to conceptualize and theorize China's international engagement and diplomacy. ${ }^{3}$ Based on their achievements, this essay explores the theoretical meaning of China's foreign assistance policy and practices, and some possible improvements of the theory. It argues that Chinese foreign assistance theory has at least four features, namely, adhering to the basic goal of prioritizing development without setting any precondition; supporting the independent development of the recipient countries, yet refraining from entrenching special bureaucratic interests of both national and international development industries; pursuing equal and inclusive development rather than moral preaching which is often adopted by traditional donors; and always

${ }^{2}$ There are few comprehensive discussions about the characteristics of China's foreign assistance. See Zhang Haibin, Fazhan Yindaoxing Yuanzhu: Zhongguo dui Feizhou Yuanzhu Moshi Yanjiu [Assistance for Leading to Development: On Models of China's Aid to Africa] (Shanghai: Shanghai People's Publishing House, 2012); Zhou Hong, "Zhongguo Yuanwai Liushinian de Huigu yu Zhanwang [Sixty Years' China Aid: Reflections and Prospects]," Foreign Affairs Review, Vol. 27, No. 5 (September/October 2010); Zhou Hong, "Zhongguo Duiwai Yuanzhu yu Gaige Kaifang Sanshinian [China's Foreign Aid and 30 Years of Reform and Opening Up]," World Economy and Politics, No. 5 (May 2008); Zhang Changyu, "Duiwai Jingji Hezuo Liushinian: Huigu yu Zhanwang [China's 60-year Foreign Economic Cooperation: Review and Prospect]," International Economic Cooperation, No. 2 (February 2009); Diao $\mathrm{Li}$ and He Fan, “Zhongguo Duiwai Yuanzhu Zhanlue Fansi [Reflections on China's Foreign Assistance Strategy]," Journal of Contemporary Asia and Pacific Studies, No. 6 (November/ December 2008), pp. 120-133.

${ }^{3}$ In the past decade, with a series of ceremonies, for example, the 50th anniversary of the Five Principles of Peaceful Coexistence established in 1954, the 30th anniversary of the Reform and Opening-up Policy announced in 1978, the 60th anniversary of the establishment of the PRC in 1949, and the 90th anniversary of the creation of the CPC in 1921, etc., China's academic community has done numerous research to conceptualize and theorize China's international engagement and diplomacy. See, for example, Yang Jiemian et al., Zhongguo Gongchandang he Zhongguo Tese Waijiao Lilun yu Shijian [The CPC and Theory and Practice of Diplomacy with Chinese Characteristics] (Shanghai: Oriental Publishing Center, 2011); Qi Pengfei, ed., Zhongguo Gongchandang yu Dangdai Zhongguo Waijiao (1949-2009) [The CPC and Contemporary Chinese Diplomacy (1949-2009)] (Beijing: CPC History Press, 2010); Yu Xintian et al., Guoji Tixi Zhong de Zhongguo Juese [China's Role in the International System] (Beijing: Encyclopedia of China Publishing House, 2008). 
keeping strategic patience when practicing development aid. Combining all these four distinctive aspects together, the nascent Chinese foreign assistance theory could serve as a complement to the traditional foreign aid theory.

\title{
Taking Development as Top Priority
}

As a developing country, China always emphasizes that development without any precondition should be the most important criterion when delivering foreign assistance, which could be named as "developmentoriented" assistance. ${ }^{4}$ That means China consciously refuses to set any precondition before many development goals, thus intentionally or unintentionally avoiding the conditions-first approach.

Given its double identities as both aid donor and recipient, China defines the fundamental goals of its foreign assistance as follows:

\section{China emphasizes actual effect rather than preconditions of development in}

\begin{abstract}
providing aid.
Unremittingly helping recipient countries build up their self-development capacity. Practice has proved that a country's development depends mainly on its own strength. In providing foreign aid, China does its best to help recipient countries to foster local personnel and technical forces, build infrastructure, and develop and use domestic resources, so as to lay a foundation for future development and embarkation on the road of self-reliance and independent development. ${ }^{5}$
\end{abstract}

\footnotetext{
${ }^{4}$ Professor Zhang Haibin sees China's foreign assistance as "assistance for leading to development" which puts development at a very high priority. However, it is important to note that such a definition has two very fundamental differences from that of this paper. For one thing, the term "development-oriented" emphasizes more the steadiness of such an approach, the other is that "assistance for leading to development" still takes conditions of development for granted, to some extent. See Zhang, Assistance for Leading to Development: On Models of China's Aid to Africa, pp. 96-97.

${ }^{5}$ Information Office of the State Council of the People's Republic of China, China's Foreign Aid (White Paper), April 2011, Beijing, http://www.scio.gov.cn/zxbd/nd/2011/Document/896900/896900.htm.
} 
In other words, China places the highest priority on these development goals when delivering foreign assistance. In practice, such an approach has two main elements, namely, promoting development goals instead of preconditions for development, and emphasizing development effectiveness instead of aid effectiveness.

\section{Prioritizing Development in the Development-Security Nexus}

The "development-oriented" or "development-first" approach means that China's foreign assistance aims to promote not only the development of recipient countries but also their willingness to pursue development. There are always conflicting goals in the decision-making process, in which development vs. security might be one of the most important pairs. How to deal with the development-security nexus or to develop a balanced approach? Through its development-first approach in the past three decades, China's experience provides new solutions. On the eve of reform and opening up in late 1978, China found itself entangled with plenty of problems on development and security, some of which were even worse than those faced by most African countries today. ${ }^{6}$ As former Chairperson of the African Union Commission Jean Ping pointed out,

Barely fifty years ago, outside of Japan, all of Asia was still in a hopeless situation of underdevelopment comparable to ours. Famine then had a name, China, and poverty was called India. ${ }^{7}$

It was the development-first approach that enabled China to overcome most of its serious development and security challenges and begin to emerge as a global power. Based on its past experience, China's foreign aid projects are targeted at areas such as agriculture, industry, economic infrastructure, public facilities, education, and health care, focusing on improving industrial and agricultural productivity of recipient countries, in

${ }^{6}$ On the development-security nexus, see Zhang Chun, “'Fazhan-Anquan Guanlian': Zhongmeiou Duifei Zhengce Bijiao ['Development-Security Nexus': A Comparative Study of the Africa Policies of China, the EU, and the U.S.]," Chinese Journal of European Studies, No. 3 (May/June 2009), pp. 69-73

7Jean Ping, And Africa will Shine Forth: A Statesman's Memoir (New York: International Peace Institute, 2012), “Introduction,” p. 6. 
order to lay a solid foundation for their economic and social development. In recent years, combating climate change has become a new component within China's foreign aid package. ${ }^{8}$ By doing so, China hopes to strengthen the self-development capabilities of recipient countries, and help develop their national industries to create more jobs and improve the living standard of local people.

This development-oriented or development-first approach is widely welcomed by recipient countries, especially those in Africa. As a report by the African Development Bank (AfDB) points out, the China-African relationship now is an evolving partnership.

China is a valuable trading partner, a source of investment financing, and an important complement to traditional development partners. China is investing massively in infrastructure, which helps alleviate supply bottlenecks and improve competitiveness. ${ }^{9}$

China's coherent aid policy also strengthens recipient countries' appetite for self-development, which is in stark contrast with the volatile nature of traditional and multilateral donations. Due to great success of the Marshall Plan in Europe in the 1950s, traditional donors were eager to replicate this experience in other developing countries, African ones in particular. ${ }^{10}$ At the very beginning, traditional donors focused more on investment and aid projects for promoting economic development. However, the failure of developmentalism in the 1960s made them gradually shift focus on to political and social development, as well as aid to create or improve conditions of economic development, which opened the door to attachment of political and social conditions for aid delivery. In the 1990s, along with the wide

${ }^{8}$ Information Office of the State Council of the People's Republic of China, China's Foreign Aid (White Paper), April 2011, Beijing, http://www.scio.gov.cn/zxbd/nd/2011/Document/896900/896900.htm; Feng Cunwan, "Nannan Hezuo Kuangjia Xia de Zhongguo Qihou Yuanzhu [China's Climate Assistance within the Framework of South-South Cooperation]," Global Review, Vol. 7, No. 1 (January/February 2015), pp. 34-51.

${ }^{9}$ Richard Schiere, “China and Africa: An Emerging Partnership for Development? - An Overview of Issues," Working Paper, No. 125 (Abidjan, Côte d'Ivoire: African Development Bank Group, May 2011), pp. 6-7, 17.

${ }^{10}$ Dambisa Moyo, Dead Aid: Why Aid is Not Working and How There is a Better Way For Africa (New York: Allen Lane, 2009), pp. 12, 35-36. 
spread of Western democracy and the neo-liberal model, a revised form of developmentalism returned. ${ }^{11}$ It is noteworthy that the philosophy of traditional donors gradually shifted from being development-oriented to

China always respects the recipients' willingness for self-development. condition-oriented during this process, intentionally or unintentionally, and the content of development course changed as well. As Dambisa Moyo argues, "democracy was the donor's final refuge; the last-ditch attempt to show that aid interventions could work, would work, if only the political conditions were right." ${ }^{\prime 2}$

\title{
Promoting Development Effectiveness Rather than Aid Effectiveness
}

The development orientation of China's foreign assistance is embodied in its pursuit of development effectiveness, rather than aid effectiveness pursued by traditional donors. To guarantee development effectiveness, China always delivers and distributes its aid in a quick and efficient manner. As former President of Senegal, Abdoulaye Wade said,

\begin{abstract}
But Western complaints about China's slow pace in adopting democratic reform cannot obscure the fact that the Chinese are more competitive, less bureaucratic and more adept at business in Africa than their critics. ${ }^{13}$
\end{abstract}

By the same token, Chinese aid decision is based more on development needs of recipient countries, with an emphasis on local capacity of selfdevelopment. For example, China always attaches importance to agriculture and rural development and poverty reduction of developing countries. By the end of 2009, China had launched 221 agricultural aid projects in

${ }^{11}$ Howard J. Wiarda, "Introduction: The Western Tradition and Its Export to the NonWest," in Howard J. Wiarda and Steven Boilard, eds., Non-Western Theories of Development: Regional Norms versus Global Trends (New York: Harcourt Brace College Publishers, 1999), pp. 1-2, 9 .

${ }^{12}$ Moyo, Dead Aid: Why Aid is Not Working and How There is a Better Way For Africa, p. 24.

${ }^{13}$ Abdoulaye Wade, “Time for the West to Practice what it Preaches," Financial Times, January 24, 2008. 
other developing countries - 35 farms, 47 agro-technology experiment and promotion stations, 11 animal husbandry projects, 15 fisheries projects, 47 farmland-irrigation and water-conservancy projects, and 66 other types of agricultural projects. ${ }^{14}$ In another example, China has significant comparative advantages in the field of infrastructure building, which could greatly help recipient countries. A report from AfDB states that China's investment in the African infrastructure sector remained stable at around $\$ 5$ billion per year in the period from 2005 to 2009, and increased almost 80 percent to 9 billion in 2010. In contrast, commitments from other donors such as India, the Arab Fund, and the African Regional Development Bank remained on a stable level of $\$ 2.7$ billion in $2010 .^{15}$

Due to failures in the past four decades, traditional donors gradually shifted away from "aid-as-entitlement" concepts toward an emphasis on results and performance since the early 1990s, which resulted in a broadbased consensus on aid effectiveness measured by clear development results. ${ }^{16}$ Such a focus on aid effectiveness has put the cart before the horse, led to ignorance of development effectiveness and technicalization of development aid. However, such an approach highlights the Chinese exceptionalism. As a 2007 IMF report argues, Chinese aid focuses on infrastructure funding like power (mainly hydropower), transport (mainly railways), information and communication technologies - none is of enough interest to traditional donors. ${ }^{17}$

\section{Building Win-Win Relationships}

It is undeniable that national interest is always one of the key rationales of international relations, and this principle also doubtlessly applies to foreign

\footnotetext{
${ }^{14}$ Information Office of the State Council of the People's Republic of China, China's Foreign Aid (White Paper), April 2011, Beijing, http://www.scio.gov.cn/zxbd/nd/2011/Document/896900/896900.htm.

${ }^{15}$ Richard Schiere and Alex Rugamba, “Chinese Infrastructure Investments and African Integration," Working Paper, No. 127 (Abidjan, Côte d'Ivoire: African Development Bank Group, May 2011), pp. 14-15.

${ }^{16}$ UNDP, Development Effectiveness: Review of Evaluative Evidence (New York: UNDP, 2001), p. 5.

17Jina-Ye Wang, “What Drives China's Growing Role in Africa?” IMF Working Paper, WP/07/211, 2007.
} 
assistance. China never argues that its foreign aid is implemented out of sheer altruism and that it does not care about national interests; ${ }^{18}$ however, China tries hard to respect national interests of recipient countries when providing development assistance. To promote self-development of recipient countries serves China's national interests. Through talent training, infrastructure improvement, and natural resources exploration, China hopes to lay a solid basis for sustainable and independent local development. By doing so, China pursues win-win goals that avoid selfishness and dependency, either political or economic, of the recipient countries, thus curbing the bureaucratic interests of so-called development industry.

\section{Not to Create Dependency}

China has never intended to create political dependency in recipient countries. When proposing the "Eight Principles" of foreign assistance in 1964, then Chinese Premier Zhou Enlai declared that the goal of China's foreign assistance was not to create dependency on China by recipient countries, but to guide them onto self-dependent paths. China understands that this will be a long-term process, as Premier Zhou pointed out to delegates from 14 West Asian and African countries between late 1963 and early 1964,

It's unrealistic to ask newly independent African countries to cast off foreign aid and achieve self-dependence right now. For them, a more realistic way out is to use aid but not depend on aid, gradually develop the national economy for the future possibility of casting off foreign aid. ${ }^{19}$ (Author's translation)

In contrast, given their long colonial history and ideological and strategic interests in recipient countries, traditional donors can hardly avoid increasing the political dependency of their recipients when delivering foreign aid. For example, the Europe Union (EU) and its members have complicated colonial linkages with the African, Caribbean, and Pacific countries (ACP). To preserve their influence and privileges from the

\footnotetext{
${ }^{18}$ It is important to note that Chinese President $\mathrm{X} i$ Jinping does advocate a new view on morality and interests, indicating a more altruist tendency in China's foreign assistance.

19“'Outline of Fourteen Countries Visit Report," Document, No. 203-00494-01, Chinese Foreign Ministry, pp. 18-19.
} 
colonial age, the EU considers foreign aid as a tool. ${ }^{20}$ Thus, European countries set up the Development Fund for the Overseas Countries and Territories in 1957, which evolved into the European Development Fund later, then signed two Yaoundé Agreements and four Lome Conventions, followed by the most recent Cotonou Agreement signed in 2000. The World Trade Organization (WTO) finally ended such a unilateral preferential treatment, and the replaced proposal, Economic Partnership Agreement, has been postponed for almost eight years due to some hidden agenda that ACP states were wary of, especially the African countries. ${ }^{21}$

Some scholars warn about the possibility of deterioration on debt concessionality that could bring some risks to debt sustainability, considering that China is now increasing its foreign assistance to Africa. However, according to an OECD research paper in 2008, on how China is impacting on the parameters of debt sustainability indicators, this has not yet been the case. In fact, China has a positive impact on debt sustainability through stimulating exports and GNP. ${ }^{22}$ Indeed, to avoid deterioration of African debt, China has always been supporting African countries to reduce debts through their own efforts, relieving their debt burden owed to China. From 2000 to 2009, China has written off 312 debt payments for 35 African countries, totaling 18.96 billion yuan (RMB). The above-mentioned debt relieving measures demonstrate China's determination and aspiration to help Africa, which also

China does its best to help prevent overdependency of the recipients on its aid, and to curb bureaucratic interests of the development industry. speeds up the process of debt reduction for

${ }^{20}$ D. Chinweizu, "Africa and the Capitalist Countries," in Ali Mazrui, ed., The General History of Africa, Vol. VIII Africana since 1935 (Oxford: James Currey, 1999), p. 769.

${ }^{21}$ Zhang Chun, “Quanqiu Jingji Weiji Xia Feizhou Diqu Yitihua de Tiaozhan [Challenges Posed by the Global Economic Crisis to African Regional Integration]," African Studies, Vol. 1, No. 1 (2010), pp. 260-261.

${ }^{22}$ Helmut Reisen and Sokhna Ndoye, "Prudent versus Imprudent Lending to Africa: From Debt Relief to Emerging Lenders," Working Paper, No. 268 (Paris, France: OECD Development Center, February 2008), pp. 38-39. 
Africa by other countries. ${ }^{23}$ As S. Ibi Ajayi describes, for various reasons, the debt crisis in Africa and the developing world in general has been derived from huge aid by traditional and multilateral donors; with selfish consideration of bureaucratic interests, such aid created economic dependency and a master-slave relationship. One of the consequences might be that the developing world is interminably trapped in underdevelopment, dependency, and poverty. ${ }^{24}$

\section{Not to Build Development Industry}

In practice, China's foreign assistance does not promote bureaucratic interests of the development industry. With decentralized foreign assistance agencies, China encourages cross-departmental coordination and cooperation in the implementation of various projects, fully respecting the demands of recipient countries in order to benefit their people. Although many propose to build a centralized and professional development agen$\mathrm{cy}^{25}$ the current system or institutional arrangement does help restrain the entrenchment of bureaucratic interests. Key departments dealing with foreign assistance in China include the Ministry of Commerce (MOFCOM), the Ministry of Foreign Affairs (MoFA), the Ministry of Finance (MOF), and China's Export and Import Bank (EXIM Bank). The Ministries of Education, Health, and Agriculture, among others, might have greater voices in their fields respectively. As the top administrator, the State Council retains the power to make final decisions. Any grant more than USD 1.5 million and/or assistance over RMB 100 million should be approved by the State Council. In spite of some complex procedures, different governmental agencies can be quickly mobilized due to the absence of a monopolizing organization, which embodies the high efficiency of China's foreign assistance.

One has to confess that bureaucratic interests of the development industry have significant impact on the decision and implementation of both

${ }^{23}$ Information Office of the State Council of the People's Republic of China, "ChinaAfrica Economic and Trade Cooperation," December 2010, Beijing, http://english.gov.cn/ official/2010-12/23/content_1771603.htm.

${ }^{24}$ S. Ibi Ajayi, "Issues of Globalisation in Africa: The Opportunities and the Challenges," Ibadan Journal of the Social Sciences, Vol. 2, No. 1 (2004), pp. 23-42.

${ }^{25}$ Zhang Hongmin, ed., Zhongguo he Shijie Zhuyao Jingjiti yu Feizhou Jingmao Hezuo Yanjiu [A Study of Economic and Trade Cooperation between Africa and China and other Major Economies] (Beijing: World Affairs Press, 2012), pp. 459-460. 
traditional and multilateral donors. As Dambisa Moyo asked, given what we know about foreign aid, and how it encourages and sustains corruption, why do Western governments insist on parceling out aid to poor countries? One of the practical explanations is that

[t]here is simply a pressure to lend. The World Bank employs 10,000 people, the IMF over 2,500; add another 5,000 for the other UN agencies; add to that the employees of at least 25,000 registered NGOs, private charities and the army of government aid agencies: taken together around 50,000 people, the population of Swaziland... Their livelihoods depend on aid, just as those of the officials who take it. For most developmental organizations, successful lending is measured almost entirely by the size of the donor's lending portfolio, and not by how much of the aid is actually used for its intended purpose... Donors are subject to "fiscal year" concerns: "they feared the consequences within their agencies of not releasing the funds in the fiscal year for which they were slated." 26

Based on such consideration of bureaucratic interests, donors, both traditional and multilateral ones, compete with each other to lend and meet their "fiscal year" concerns, but sacrifice the actual needs of recipient countries. Taking Tanzania as an example, it received more than 1,500 aid commitments between 2001 and 2003, from more than 50 bilateral and multilateral donors, ${ }^{27}$ and most of these commitments were devoted to environmental protection for the minimization of negative impacts of economic development. Not for the sake of development itself, but for influence and lending, these donors' competition in Tanzania has created negative consequences. The percentage of forest coverage between 2000 and 2005 even decreased by 10 percent compared with that of $1990-2000 .^{28}$ In other words, traditional and multilateral donors actually do the same thing for meeting their

${ }^{26}$ Moyo, Dead Aid: Why Aid is Not Working and How There is a Better Way For Africa, p. 54.

${ }^{27}$ D. Roodman, "Competitive Proliferation of Aid Projects: A Model," Working Paper, No. 89 (Washington, D.C.: Center for Global Development, November 2011), June 2006, p. 2.

${ }^{28}$ Forest Resources and Assessment 2005: Global Synthesis (Rome, Italy: Food and Agriculture Organization, 2005), pp. 22, 196. 
own "fiscal year" target instead of promoting development when they accuse their recipients of earmarking for money.

\section{Highlighting Equality and Mutual Trust}

The third characteristic of China's foreign assistance lies in its basic attitude toward recipient countries, namely equality and inclusiveness, without preaching about how to develop their economies. For one, China always insists on the non-intervention principle and attaches no strings to its assistance. For another, China stresses that the imposed concept of "the China model" does not imply universality of China's experience. Each country can and should find its own pathway of development. This might be the reason that China's development assistance has been much welcomed in many countries.

\section{No-Strings-Attached Approach}

Equality is one of the core principles that guide China's foreign relations as well as development assistance in particular. The first two of China's eight principles for economic aid and technical assistance to other countries, issued in January 1964, state that:

(1) The Chinese government always bases itself on the principle of equality and mutual benefit in providing aid to other countries. It never regards such aid as a kind of unilateral favor but as something mutual.

(2) In providing aid to other countries, the Chinese government strictly respects the sovereignty of recipient countries, and never attaches any conditions or asks for any privileges. ${ }^{29}$

And the "equal and mutual benefit" principle was placed on top of the four principles for China's foreign aid initiated in the early 1980s. The 2011 White Paper of China's Foreign Aid also states:

- Imposing no political conditions. China upholds the Five Principles of Peaceful Coexistence, respects recipient countries' right to independently

${ }^{29}$ Information Office of the State Council of the People's Republic of China, China's Foreign Aid (White Paper), April 2011, Beijing, "Appendix 1," http://www.scio.gov.cn/zxbd/ nd/2011/Document/896900/896900.htm. 
select their own path and model of development, and believes that every country should explore a development path suitable to its actual conditions. China never uses foreign aid as a means to interfere in recipient countries' internal affairs or seek political privileges for itself.

- Adhering to equality, mutual benefit and common development. China maintains that foreign aid is mutual help between developing countries, focuses on practical effects, accommodates recipient countries' interests, and strives to promote friendly bilateral relations and mutual benefit through economic and technical cooperation with other developing countries. $^{30}$

Such an attitude is widely welcomed by recipient countries, especially in Africa. Although many Western reports highlight an anti-Chinese mood arising in Africa, the mainstream polling results prove just the opposite; for example, according to the Pew Global Attitudes Project, China's influence in Africa is almost universally viewed more positively than that of the United States. $^{31}$

However, in the eyes of traditional donors, the non-interference principle and no-strings-attached approach "undermines" their efforts to improve human rights records and good governance in recipient countries. The reasons that China adopts such an approach, according to Western scholars and politicians, lie in its greedy needs for natural resources and commercial opportunities and even a practice of neocolonialism. As a U.S. scholar writes, development assistance without any conditionality

has spurred some fears that Western influence in Africa will thereby be diminished and that investments in governance, transparency, and accountability will be undermined, particularly

${ }^{30}$ Information Office of the State Council of the People's Republic of China, China's Foreign Aid (White Paper), April 2011, Beijing, http://www.scio.gov.cn/zxbd/nd/2011/Document/896900/896900.htm.

31 “U.S. Favorability Ratings Remain Positive, China Seen Overtaking U.S. as Global Superpower," Pew Global Attitudes Project, July 13, 2011, http://www.pewglobal.org/2011/ 07/13/china-seen-overtaking-us-as-global-superpower/; Andrew Kohut, "How the World Sees China," Pew Global Attitudes Project, December 11, 2007, http://pewresearch.org/pubs/ 656/how-the-world-sees-china. 
in natural resource-rich states whose governments lack legitimacy or national vision. ${ }^{32}$

However, according to Professor Ngaire Woods, the "support for rogue states" argument does not have evidence that economic disaster has in fact followed acceptance of aid from China. Indeed, there is now some evidence that countries with intensified aid and trade links with China are enjoying higher growth rates, better terms of trade, increased export volumes and higher public revenues. ${ }^{33}$ Another research finds that, while China's role in resource-rich countries like Angola and

China insists on equality and mutual trust in providing aid, and tries to avoid moral preaching.
Sudan is controversial,

mutual respect is a key element of China's foreign policy and even smaller African countries with relatively little economic or political significance have received large aid and investment support from China. $^{34}$

\section{Experience Sharing but not Moral Preaching}

When delivering development assistance, China does not only insist on the principle of equality, but also on inclusiveness. On one hand, China fully respects the recipients' own choices of development path and model, believing that each country has the capability to find the right way that fits their national contexts. China has a clear understanding about the "China

${ }^{32}$ Carola McGiffert, "Chinese Soft Power and Its Implications for the United States: Competition and Cooperation in the Developing World," CSIS Smart Power Initiative Report (Washington, D.C.: Center for Strategic and International Studies, March 10, 2009), p. 29.

${ }^{33}$ Ngaire Woods, "Whose aid? Whose influence? China, Emerging Donors and the Silent Revolution in Development Assistance," International Affairs, Vol. 84, No. 6 (November/December 2008), pp. 1207-1208.

${ }^{34}$ M. Davies, H. Edinger, N. Tay and S. Naidu, How China Delivers Development Assistance to Africa (Stellenbosch, South Africa: Center for Chinese Studies, University of Stellenbosch, February 2008), p. 5. 
model" argument as well as the motivation behind such rhetoric. Generally speaking, there is no consensus within the official and academic circles on the so-called "China model," neither is there any attempt to spread this "model" to other countries. China prefers to share "Chinese experience" with recipient countries through, for example, technical cooperation, human resource development, and so on. So far, China has helped African countries build six Sino-African economic zones for exploring specific models and ways for Africa. ${ }^{35}$

On the other hand, China actively participates in international cooperation on foreign aid. In addition to developing bilateral assistance, China also gets involved in trilateral and regional collaboration with other countries and some multilateral organizations in capacity building, training, and infrastructure construction. Under the trilateral cooperation pressure mostly from the traditional donors, ${ }^{36}$ China agrees to work with all parties concerned to conduct complementary and fruitful trilateral and regional cooperation on the basis of respecting the needs of recipient countries under the framework of South-South cooperation. For example, Chinese Premier Li Keqiang announced the three principles for trilateral cooperation in Africa in May 2014 when delivering his speech at the 24th World Economic Forum on Africa,

China is also ready to step up its collaboration with international organizations and relevant countries to explore trilateral and multilateral cooperation based on the principles of "African needs, African consent and African participation" and make a joint contribution to Africa's development. ${ }^{37}$

${ }^{35}$ Jean-Claude Berthelemy, "China's Engagement and Aid Effectiveness in Africa," Working Paper, No. 129 (Abidjan, Côte d'Ivoire: African Development Bank Group, 2011), p. 28.

${ }^{36}$ On pressures of trilateral cooperation in Africa from traditional donors, see Zhang Chun, "Zhongfei Guanxi: Yingdui Guoji Duifei Hezuo de Yali he Tiaozhan [China-Africa Relations: How to Deal with Pressures of International Cooperation in Africa]," Foreign Affairs Review, No. 3 (May/June 2012), pp. 36, 41-42.

37 "Work Together to Scale New Heights in African Development," Address by Chinese Premier Li Keqiang at the 24th World Economic Forum on Africa, May 8, 2014, Chinese Foreign Ministry website, May 8, 2014, http://www.fmprc.gov.cn/mfa_eng/topics_665678/ lkqzlcfasebyfmnrlyaglkny/t1157616.shtml. 
In contrast, traditional donors tend to believe that they are leaders in development and know better how to achieve development, and thus take a closed-minded view and try to teach recipient countries how to develop. To a great extent, foreign aid or development assistance has become an entrenched belief, even a myth, in the traditional donors' circles. On one hand, they believe that it is a time-honored truth that all nations will gradually enjoy "development" achievements; as a matter of fact, such belief is based on "local universalism." It is an unwise attempt for a society to impose its self-believed and historically constructed values onto other societies. ${ }^{38}$ On the other hand, based on linear thinking, traditional donors believe that to realize Western-style development equates to "progress"; however, such a "development" may cause profound damages to a society, thus the "progress" in the eyes of traditional donors is but a kind of vague ideology. ${ }^{39}$ Based on these two erroneous assumptions, traditional donors try very hard to transplant their own development model into other societies, which justifies the conditionality of aid. A natural consequence of this self-proclaimed moral/ethical advantage is that the call for trilateral cooperation by traditional donors does not mean they are now open to all development models and paths; rather, it implies that their aid is a kind of "charity" or "lifeline." Since the emerging donors are potential destroyers of this system, traditional donors try to regulate or socialize them through potential trilateral cooperation.

\section{Keeping Strategic Patience}

In addition to the above characteristics, China also keeps strategic patience when providing foreign aid. Long-term and comprehensive approaches are always adopted to promote development in recipient countries. In most cases, China warns against the trends of finding technical, once-and-for-all "panacea" solutions.

${ }^{38}$ Gilbert Rist, Le Développement, Histoire d'une Croyance Occidentale, Chinese Edition, trans., Lu Xianggan (Beijing, Social Sciences Academic Press, 2011), p. 40.

${ }^{39}$ John H. Bodley, Victims of Progress (Walnut Creek, California: Altamira Press, 2008); Pan Yaling, "Xifang Guoji Guanxi Lilun de 'Jingbu' Yishi Xingtai [The Progressive Ideology in Western International Relations Theories]," International Forum, No. 4 (July/August 2005). 


\section{Long-Term and Comprehensive Strategic Planning}

Many international analysts and observers argue that China's foreign assistance is simply driven by a thirst for natural resources in general, oil and gas in particular. ${ }^{40}$ In fact, China develops relations with recipient countries with a much broader vision, hoping to promote their sustainable development based on mutual friendship. China does not pursue short-term interests at the expense of long-term strategic concerns.

Out of strategic considerations, most of China's aid programs and projects are long-term and comprehensive in nature. First of all, internal elements of China's aid are highly harmonized. Financial resources for foreign aid usually fall into three categories: grants (aid gratis), interest-free loans, and concessional loans. The newly issued Measures for the Administration of Foreign Aid by MOFCOM in December 2014 clarifies the two criteria for choosing different types of foreign assistance, namely local needs plus local economic returns: if there are no needs, then no assistance is provided; based on local needs, if economic returns are low (public infrastructure projects for example), then grants are given; if economic returns are average, then interest-free loans; and if economic returns are high, then concession loans. ${ }^{41}$ China offers foreign aid in eight forms: complete projects, goods and materials, technical cooperation, human resource development cooperation, medical teams, humanitarian aid, volunteer programs, and debt relief. Regarding the distribution of its foreign aid, China sets great store by people's living conditions and economic development of recipient countries, making great efforts to ensure that its aid benefits as many needy people as possible. ${ }^{42}$

Secondly, China's aid always maintains continuity, not only in general guidelines and policy principles but also project and program implementation. For example, since the first medical team was sent in 1963, China's

\footnotetext{
${ }^{40}$ See, for example, Stefan Halper, The Beijing Consensus: How China's Authoritarian Model Will Dominate the Twenty-first Century (New York: Basic Books, 2010); Penny Davies, China and the End of Poverty in Africa-towards Mutual Benefit? (Sundyberg, Sweden: Diakonia, August 2007); Moisès Naím, “Rogue Aid," Foreign Policy, Vol. 159 (March/April 2007), pp. 95-96.

${ }^{41}$ Measures for the Administration of Foreign Aid, No. 5, 2014, MOFCOM Regulation, November 15, 2014, http://www.mofcom.gov.cn/article/b/c/201411/20141100799438.shtml.

${ }^{42}$ Information Office of the State Council of the People's Republic of China, China's Foreign Aid (White Paper), April 2011, Beijing, http://www.scio.gov.cn/zxbd/nd/2011/Document/896900/896900.htm.
} 
medical team initiatives have experienced four stages of development, namely inauguration, fast expansion, transformation, and full-fledged development. Sending medical teams has not only been a specific aspect of China's foreign assistance, but become a tradition as well. ${ }^{43}$ From 1963 to 2014, 23,000 medical workers have been sent to 66 countries and regions, delivering services to 270 million people, according to China's official statistics. Furthermore, 50 Chinese medical workers have died on foreign aid missions over the past five decades - a big sacrifice yet marked example of China's contribution to international development. Currently, 1,171 Chinese medical workers are serving in 113 medical centers in 49 countries and regions, with 42 workers being stationed in Africa. ${ }^{44}$

\section{China encourages} sustainable development of the recipient countries rather than eagerness for quick fixes.
Finally, early planning for its foreign aid programs and projects has long been maintained as a Chinese tradition. In 2000, China and Africa jointly established the Forum on China-Africa Cooperation (FOCAC). A ministerial conference was then held every three years in order to review achievements and make new working principles and action plans. In 2013, China started to draft its longterm foreign assistance strategy and national foreign assistance strategies until 2030, which will hopefully be publicized in $2015 .{ }^{45}$

\section{Neither Panacea nor Technicalization for Development}

With a strategic view, China keeps patience on both aid effectiveness and self-development of recipient countries. China never hopes to solve all problems by delivering a single (set of) aid program. Based on its own development experience, China advocates a gradual and steady approach.

${ }^{43}$ For the contributions of medical teams to China's soft power, see Zhang Chun, "Yiliao Waijiao yu Ruanshili Peiyu: Yi Zhongguo Yuanfei Yiliaodui Weili [Health Diplomacy and Soft Power Building]," Contemporary International Relations, No. 3 (March 2010).

44 "China Marks 50th Anniversary of First Overseas Medical Aid Mission," Xinhua News, August 15, 2013, http://news.xinhuanet.com/english/china/2013-08/15/c_132633920. htm.

${ }^{45}$ Personal exchanges with MOFCOM officials, September 25, 2014, Beijing. 
Thus, China believes in recipient countries' capabilities in finding the right way to develop, on the premise that enough ownership and policy space are provided. China keeps pace with the times and pays attention to reform and innovation, adapting its foreign aid to the development of both domestic and international situations by summarizing experiences and adjusting the management mechanism, so as to constantly improve its foreign aid initiatives. ${ }^{46}$

In contrast, aid from traditional donors lacks such sensitivity to strategy and tends to emphasize more the technical dimension and shortsighted "panacea" solutions. Development studies reached its first climax in the 1960s, thanks to the impetus to copy the success of the Marshall Plan in the third world, providing a "better" development model (compared to that of the communist camp) in the context of the Cold War, and justifying the survival of international development aid agencies after the end of the Marshall Plan. ${ }^{47}$ The failure of modernization projects in the 1960 s led traditional donors to explore the root causes and search for new solutions, which nurtured a tradition of finding a once-and-for-all solution or "panacea" that dominated the subsequent history of development practice. In the past five decades, the world witnessed continuous change of development themes every 10 years, ${ }^{48}$ aid for "industrialization" (1960s), followed by aid for "poverty eradication" (1970s), then aid contingent upon "structural adjustment" (1980s), then aid based on "good governance and democratization" (since 1990), ${ }^{49}$ then aid effectiveness (2000s), and currently an embryonic approach of result management.

${ }^{46}$ Information Office of the State Council of the People's Republic of China, China's Foreign Aid (White Paper), April 2011, Beijing, http://www.scio.gov.cn/zxbd/nd/2011/Document/896900/896900.htm.

${ }^{47}$ On the evolution of development industry, see Howard J. Wiarda, Political Development in Emerging Nations: Is There Still a Third World (Belmont, California: Thomson/Wadsworth, 2004), chap. 2.

${ }^{48}$ Laurence Chandy, "Reframing Development Cooperation," in Global Economy and Development at Brookings ed., From Aid to Global Development Cooperation, Brookings Blum Roundtable Policy Briefs (Washington, D.C.: Brookings Institution, 2011), p. 5.

${ }^{49}$ Erik Thorbecke, “The Evolution of the Development Doctrine, 1950-2005," UN University Research Paper, No. 2006/155, December 2006; Moyo, Dead Aid: Why Aid is Not Working and How There is a Better Way For Africa, pp. 8, 11-20. 
The fascination with "panacea" also nurtures a trend of technicalization of traditional donors' aid, resulting in ignorance of development effectiveness. As Duflo and Kramer have pointed out, the most important progress of development studies since the beginning of the twenty-first century are all technical but not theoretical, for example, to use random and controlled experiments to evaluate the effectiveness of aid. ${ }^{50}$ Such an effort to seek panacea and technical solutions brings serious disturbance to recipient countries. The development theme changes every ten years, which means the recipient countries have to re-learn how to write application and evaluation reports every ten years. More importantly, these recipients have to re-adapt themselves to new ideas and concepts every ten years, which consumes much of their time and energy for pursuing development effectiveness. Thus, a vicious circle is created where the donors are in constant pursuit of the next panacea and recipient countries have to undergo all the difficulties trying to catch up.

\section{Conclusion}

As both donor and recipient in the past six decades and more, China has developed an embryonic theory of foreign assistance with four distinctive features: prioritizing development without setting any precondition, building win-win relations with recipient countries through promotion of their independent development and national interests, insisting on equality rather than moral preaching, as well as keeping strategic patience while avoiding technical short-sightedness. Carried out on a small scale and a few platforms, and working under an improving legal system, China's foreign assistance has made great achievements that attract growing international attention.

It is important to note that China's foreign assistance, both in practice and in theory, is still at the rudimentary stage. Improving such theory and practice could bring broader implications for the building of China's theories of international relations and diplomacy. For one thing, it can provide more systematic, theoretical, and strategic guidelines for China's practice of

${ }^{50}$ E. Duflo and M. Kramer, "Use of Randomization in the Evaluation of Development Effectiveness," paper prepared for the World Bank Operations Evaluation Department Conference in Washington D.C., July 15-16, 2003. 
development assistance, improving China's performance and easing suspicions and criticisms from the international community. For another, it will contribute more global intellectual public goods by building China's theories of international relations and diplomacy. Three points need to be highlighted for further improvement of China's foreign assistance theory.

First, the experience and specialties of China's foreign assistance need to be summarized and further refined. Under the circumstances of donor diversification, better theoretical frameworks foretell a brighter future for China's foreign assistance. We need to think more about the relationship between China's development aid and South-South cooperation, the specialties and commonalities between China and other emerging donors, what contributions China can make to the reform of traditional and multilateral donors in both mentality and mechanism, as well as how China can contribute to future international development cooperation, for example, the UN post-2015 development agenda.

Second, the way to strengthen the pros and address the cons of China's foreign assistance needs to be further explored. The fact that China's success is based on a small amount of aid and relatively defective legal and platform system has not gone unnoticed in international criticism. Should China develop a unified, strong foreign assistance platform, with the risks of entrenching bureaucratic interests, following the instruction of international observers? Should China follow the traditional donors and join the $\mathrm{OECD} / \mathrm{DAC}$ group, risking abandoning all specialties and being abandoned by recipient countries? Decisions on such questions are determinants to China's foreign assistance development and the future of China's international position.

Third, more ways and mechanisms for trilateral and multilateral cooperation need to be explored. While China opens to all kind of trilateral and multilateral cooperation, such practices are still at the beginning stage. How to implement the "Africa needs, Africa agrees, Africa participates" principles on the ground, how to expand these principles to all foreign assistance programs, and how to build overseeing mechanisms to uphold the above principles, are key to the future role of China in the international aid architecture. Without causing a "quiet revolution" in international aid architecture, China can best prove its political willingness through inclusive and fruitful trilateral and multilateral cooperation. 